\title{
Geochemistry and origin of tektites from Dalat area, Vietnam
}

\author{
Yung-Tan Lee', Ren-Yi Huang ${ }^{2}$, Chih-Cheng Chen ${ }^{3}$, Jyh-Yi Shih $^{1}$, \\ Meng-Lung Lin ${ }^{1}$ and Yen-Tsui $\mathrm{Hu}^{4}$ \\ ${ }^{1}$ Department of Tourism, Aletheia University, 25103, Taiwan \\ ${ }^{2}$ Department of Leisure Business Management, DeLin Institute of Technology, \\ Taipei236, Taiwan \\ ${ }^{3}$ Department of Sport Management, Aletheia University,25103, Taiwan \\ ${ }^{4}$ Sinotech Engineering Consultants Inc., Taipei 114, Tiwan
}

\begin{abstract}
We measured the major and trace element contents and $\mathrm{Rb}-\mathrm{Sr}$ isotopic compositions of 9 tektites from the Dalat area, Vietnam. All the samples studied are splash-form tektites which show pitted or grooved surfaces with schlieren structures on some surfaces. The trace element ratios $\mathrm{Ba} / \mathrm{Rb}$ (avg. 4.00), Th/Sm (avg. 2.06), Sm/Sc (avg. 0.60), Th/Sc (avg. 1.25) , La/Sc (avg. 3.48), $\mathrm{Th} / \mathrm{U}$ (avg. 6.83), and the rare earth elements (REE) contents of tektites of this study are similar to the average upper continental crust. From the chemical composition, it is suggested that tektites in this study are derived from similar parental terrestrial sedimentary deposit which may be related to post-Archean upper crustal rocks. The tektites from the Dalat area have high positive $\varepsilon^{\mathrm{Sr}}(0)$ values-ranging from 184.8 196.5 which indicate that the parental material for these tektites have similar $\mathrm{Sr}$ isotopic compositions to old terrestrial sedimentary rocks and they were not dominantly derived from recent young sediments (such as soil or loess). The $\mathrm{Sr}$ isotopic data obtained by the present study support the conclusion proposed by Blum et al. (1992)[1] that the depositional age of sedimentary target materials is close to $170 \mathrm{Ma}$ (Jurassic). Mixing calculations based on the model proposed by Ho and Chen (1996)[2] for
\end{abstract}

various amounts and combinations of target rocks indicate that the best fit for tektites from the Dalat area is a mixture of $39 \%$ shale, $29 \%$ sandstone, $32 \%$ greywacke, $1 \%$ quartzite.

Keywords: Geochemistry, Dalat area, Vietnam, Tektites.

\section{Introduction}

Tektites are terrestrial natural glasses of up to a few $\mathrm{cm}$ diameter size that are produced during the early phases of a hypervelocity impact of an asteroid or a comet into terrestrial rock [3]-[4]. The chemical and isotopic composition of tektites is similar to that of terrestrial upper continental crust which indicates that tektites must have formed by fusion of such target rock and not from projectile matter[5]. The tektites from a specific region are usually given a distinctive name derived from the geography. Previous studies of cosmogenic radioisotopes have pointed out tektites derived from the top of the impacted target lithologies [6]. Tektites are only found in a few distinct geographical areas called strewn fields which four are currently known[7]: the $\sim 35 \mathrm{Ma}$ North American strewn field associated with the Chesapeak Bay impact structure; the Central European strewn field associated with the Ries crater in 
Bavaria, Germany ( 14.7Ma); the $\sim 1.07$ Ma Ivory Coast tektite strewn field which are derived from the Bosumtwi impact structure in Ghana, and the Australasian strewn field of age $\sim 0.8 \mathrm{Ma}[8]$. The impact structure for the Australasian strewn field has not yet been found. The Australasian strewn field covers nearly $10 \%$ of the Earth's surface[9]. The Australasian strewn field extended from a small part of South China (including Hainan province) through Lao, Vietnam, Cambodia, Thailand, Malaysia, the Philippines, Brunei and North Borneo, Indonesia, to Australia. The Australasian tektites probably originated somewhere in Southeast Asia. Based on the thickness of the Australasian microtektite layer proposed by Glass and Pizzuto (1994)[10], the diameter of the source crater is estimated to be between 32 and $114 \mathrm{~km}$. The tektites from these four strewn fields are characterized by different chemical compositions, petrological properties, and ages.

The tektites found on land (as opposed to the microtektites found in deep-sea cores) can be classified into three groups: (1) aerodynamically shaped tektites; (2) normal or splash-form tektites, and (3) Muong Nong-type tektites (or layered tektites) [11]. Tektites of types (1) and (3) are predominantly found in the Australasian. The first two groups are only slight different in their appearance and physical characteristics. The splash-forms include spheres, droplets, dumbbells, and teardrops tektites, and they are generally one to a few centimeters in size. The aerodynamically shaped tektites are splash forms that may result from partial remelting of the tektite glass during atmospheric re-entry, after the initial melt had been ejected outside the terrestrial atmosphere and solidified through quenching. The splash-form tektites may result mostly from the solidification of rotating liquids. Muong Nong-type tektites named after a locality in Laos are usually considerably larger than splash-form tektites and are blocky appearance. They are larger in size, less homogeneous, having higher abundances of volatile elements and water. Muong Nong-type tektites contain more bubbles and some relict minerals (e.g., coesite, zircon, corundum, rutile, chromite, etc.) which imply a sedimentary rock as the source $\operatorname{rock}[12]$.

\section{Methodology}

Nine samples were cleaned ultrasonically and crushed into chips by a hammer wrapped with plastic sheets. Several larger glass chips were selected and ground to powder in an agate mortar. The chemical analyses of tektites from the Dalat area have been carried out by the colorimetry $(\mathrm{Si}$, $\mathrm{Al}, \mathrm{Ti}, \mathrm{P})$, atomic absorption( $\mathrm{Fe}, \mathrm{Mg}, \mathrm{Ca}$, $\mathrm{Na}, \mathrm{K}, \mathrm{Mn}$ ) and inductively coupled plasma mass spectrometry(Ba, $\mathrm{Co}, \mathrm{Cr}, \mathrm{Cs}$, $\mathrm{Cu}, \mathrm{Hf}, \mathrm{Ga}, \mathrm{Li}, \mathrm{Nb}, \mathrm{Ni}, \mathrm{Rb}, \mathrm{Sc}, \mathrm{Sr}, \mathrm{Ta}, \mathrm{Th}$, U, V, W, Y, Zr, Zn and REEs) at National Taiwan and Tsing-Hua Universities. The calibration curves were constructed using U.S.G.S. standard rocks Agv-1, BCR-1, $\mathrm{W}-2, \mathrm{G} 2$ and NBS rock standards and obsidian rock. The precision is estimated to be around $\pm 2 \%$ for colorimetric and atomic absorption methods(for trace elements around $\pm 5 \%$ ) and better than $5 \%$ for all ICP-MS analyses. Two tektites were selected for $\mathrm{Rb}-\mathrm{Sr}$ isotopic composition analyzed. Each tektite was cleaned with acetone and distilled water. Each sample was then individually dissolved in a HFHNO3 mixture, and the tracers addition(84Sr and $87 \mathrm{Rb}$ ) and chemical separations were followed. The isotopic compositions of the $\mathrm{Rb}$ and $\mathrm{Sr}$ were measured using a Finnigan MAT 261 mass spectrometer at AMDEL, Thebarton, Australia. 


\section{Result and discussions}

Based on the shape, weight, refractive index and density, the tektites from the Dalat area are splash-form tektites. On the basis of surface feature and correlation plot of refractive index versus silica content, tektites of this study can be clearly distinguished from terrestrial volcanic glasses. These tektites have a pitted or grooved surface and preserve the schlieren structures on some surface, indicating high speed entry into the atmosphere and rapid solidification in flight. Tektites from the Dalat area are characterized by high $\mathrm{SiO}_{2}$ content ranging from 71.21 to $73.90 \mathrm{wt} \%$ (avg. $72.62 \mathrm{wt} \%$ ), which is consistent with previously published analyses of Muong Nong-type and aplash-form indochinites (Table 1). The $\mathrm{SiO}_{2}$ and $\mathrm{Al}_{2} \mathrm{O}_{3}$ contents of tektites from Dalat have higher variation. Based on the high content of $\mathrm{SiO}_{2}$, the lunar volcanic origin for tektites may be excluded. The relative depletion of $\mathrm{Al}_{2} \mathrm{O}_{3}$ in tektites from Dalat area may be caused by lower shale involved during the production of tektites or different amounts and combinations of target material. Except for higher $\mathrm{CaO}, \mathrm{Na}_{2} \mathrm{O}, \mathrm{MnO}, \mathrm{Ba}, \mathrm{Co}, \mathrm{Cr}, \mathrm{Sr}, \mathrm{Ga}, \mathrm{Sc}$, Th and lower $\mathrm{Al}_{2} \mathrm{O}_{3}$ contents, the chemical composition of tektites of this study closely resemble that of splash-form indochinites. Except for $\mathrm{Al}_{2} \mathrm{O}_{3}, \mathrm{Na}_{2} \mathrm{O}$ and $\mathrm{K}_{2} \mathrm{O}$, the concentrations of the major oxides are similar to those of the upper continental crust . tektites of this study indicate that the source material probably contains relatively low contents of feldspar. The REE patterns for tektites in this study are similar to those of previously analyzed splash-form indochinites, indicating that they are all derived from similar parent rocks of upper continental crust affinity. According to major and trace elements, it is suggested that the tektites of this study resemble in composition to the upper continental crust (UCC). Some trace elements are not closely correlated between the tektites analyzed and the upper continental crust which may be related to high temperature during impact melting. When comparing with the Early, Late and postArchean upper continental crust, the REE patterns of tektites from Dalat area are quite similar to that of post-Archean upper continental crust.

Based on the $\mathrm{Nd}$ and $\mathrm{Sr}$ isotopic studies, Blum et al. (1992)[1] revealed that the Australasian tektites were derived dominantly from a sedimentary formation with a narrow range of stratigraphic ages, close to $170 \mathrm{Ma}$ (Jurassic sedimentary rocks), by a single impact event. The $\mathrm{Sr}$ isotopic data obtained by the present study support the conclusion proposed by Blum et al. (1992) [1], since our data all fall within the wedge-shaped array defined by all Australasian tektites. The tektites from the Dalat area have high positive $\varepsilon^{\mathrm{Sr}}(0)$ valuesranging from 184.8 196.5 which indicate that the parental material for these tektites have similar $\mathrm{Sr}$ isotopic compositions to old terrestrial sedimentary rocks and they were not dominantly derived from recent young sediments (such as soil or loess). On the basis of the fluence of microtektites (number per $\mathrm{cm}^{2}$ of the column) recovered from marine cores from oceanic regions near southeast Asia, the East Indies and Australian, Schmidt et al. (1993)[13] concluded that microtektite fluences tend to decrease with increasing distance from southeast Asia. The southern part of the Thailand-Laos border has non-marine Jurassic exposures suggested by Sato (1992)[14] which reveal that the source crater for Australasian strewn field appears to be located in a limited area near the southern part of the Thailand-Laos border. 
TABLE 1 Major and trace element compositions of tektites from the Dalat area compared with average Muong Nong-type and splashform indochinites, and average upper continental crust

\begin{tabular}{|c|c|c|c|c|}
\hline & Avg. D. & A & B & C \\
\hline $\mathrm{SiO}_{2}(\%)$ & 72.62 & 78.90 & 72.70 & 66.00 \\
\hline $\mathrm{Al}_{2} \mathrm{O}_{3}$ & 13.09 & 10.18 & 13.37 & 15.2 \\
\hline $\mathrm{MgO}$ & 2.70 & 1.43 & 2.14 & 2.20 \\
\hline $\mathrm{FeO}$ & 4.68 & 3.74 & 4.85 & 4.50 \\
\hline $\mathrm{CaO}$ & 1.54 & 4.20 & 1.05 & 4.20 \\
\hline $\mathrm{Na}_{2} \mathrm{O}$ & 1.29 & 0.92 & 1.98 & 3.90 \\
\hline $\mathrm{K}_{2} \mathrm{O}$ & 2.43 & 2.42 & 2.62 & 3.40 \\
\hline $\mathrm{MnO}$ & 0.10 & 0.08 & 0.08 & 0.08 \\
\hline $\mathrm{TiO}_{2}$ & 0.92 & 0.63 & 0.78 & 0.50 \\
\hline $\mathrm{Total}$ & 99.30 & 99.54 & 99.57 & 99.98 \\
\hline $\mathrm{Ba}(\mathrm{ppm})$ & 400 & 341 & 360 & 550 \\
\hline $\mathrm{Co}$ & 10.5 & 12.6 & 11.0 & 10.0 \\
\hline $\mathrm{Cr}$ & 58.8 & 60.6 & 63.0 & 35.0 \\
\hline $\mathrm{Cs}$ & 6.16 & 5.09 & 6.50 & 3.70 \\
\hline $\mathrm{Ga}$ & 7.4 & 8.13 & 6.95 & 5.80 \\
\hline $\mathrm{Li}$ & 45.2 & 42.10 & 47.10 & 20.00 \\
\hline $\mathrm{Nb}$ & 14.1 & - & - & - \\
\hline $\mathrm{Rb}$ & 100 & 110 & 130 & 112 \\
\hline $\mathrm{Sc}$ & 10.7 & 7.7 & 10.5 & 11.0 \\
\hline $\mathrm{Sr}$ & 138 & 135 & 90 & 350 \\
\hline $\mathrm{Ta}$ & 1.2 & 1.2 & 1.6 & 2.2 \\
\hline $\mathrm{Th}$ & 13.4 & 11.1 & 14.0 & 10.7 \\
\hline $\mathrm{U}$ & 1.96 & 2.48 & 2.07 & 2.80 \\
\hline $\mathrm{V}$ & 68.7 & 72 & 63 & 60 \\
\hline $\mathrm{Y}$ & 29.6 & - & - & - \\
\hline $\mathrm{Zn}$ & 9 & 280 & 252 & 190 \\
\hline $\mathrm{Zr}$ & 251 & 67 & 6 & 71 \\
\hline $\mathrm{La}$ & 37.3 & 28.2 & 36.5 & 30.0 \\
\hline $\mathrm{Ce}$ & 77.4 & 60.7 & 73.1 & 64.0 \\
\hline $\mathrm{Nd}$ & 32.8 & 29.1 & 33.2 & 26.0 \\
\hline $\mathrm{Sm}$ & 6.5 & 4.9 & 6.6 & 4.5 \\
\hline & & & & \\
\hline
\end{tabular}

The present authors selected a variety of target rocks in the literatures including average post-Archean Australian shale, average Phanerozoic sandstone, average MesoCenozoic greywacke and quartzite in Tasmania, and mixing calculations for various amounts and combinations of these rocks have been performed in order to build up a geochemical relationship between the tektites analyzed and its parent material. The model is useful in determining the most possible fit for the parent material of the tektites from the Dalat area. In the mixing model, the best fit for tektites from the Dalat area is a mixture of $39 \%$ shale, $29 \%$ sandstone, $32 \%$ greywacke, $1 \%$ quartzite.

\section{Conclusion}

All the samples studied are splash-form tektites which show pitted or grooved surfaces with schlieren structures on some surfaces. Tektites from the Dalat area are characterized by high $\mathrm{SiO} 2$ content which is consistent with previous observation on Australasian tektites. Based on the high content of $\mathrm{SiO} 2$, the lunar volcanic origin for tektites may be excluded. The relative depletion of $\mathrm{Al} 2 \mathrm{O} 3$ in tektites from Dalat area may be caused by lower shale involved during the production of tektites or different amounts and combinations of target material. Except for higher $\mathrm{CaO}, \mathrm{Na} 2 \mathrm{O}$, $\mathrm{MnO}, \mathrm{Co}, \mathrm{Sr}, \mathrm{Ga}, \mathrm{Sc}$ and lower $\mathrm{Al} 2 \mathrm{O} 3$ contents, the chemical composition of tektites of this study closely resemble that of splash-form indochinites. According to major, trace elements (including rare earth elements) and the trace element ratios $(\mathrm{Ba} / \mathrm{Rb}, \mathrm{Th} / \mathrm{Sm}, \mathrm{Sm} / \mathrm{Sc}, \mathrm{Th} / \mathrm{Sc}, \mathrm{La} / \mathrm{Sc}$ and $\mathrm{Th} / \mathrm{U}$ ), it is suggested that the tektites of this study resemble in composition to the upper continental crust (UCC). The $\mathrm{La} / \mathrm{Th}$ ratios and REE pattern indicate that the tektites in this study may be derived from post-Archean sedimentary rocks such as sandstones, greywacke and shale. Based on chemical elements and the $\mathrm{Sr}$ and $\mathrm{Nd}$ isotopic variations, we suggest that the Australasian tektites are not likely to be formed from local melting at a variety of different sites and they were not dominantly derived from recent young sediments (such as soil and loess). The tektites of the present study may be the result of melting at a single site which may be located of the southern part of the Thailand-Laos border where Jurassic non-marine sandstone, siltstone, shale, mudstone and conglomerates with minor intercalation of limestone are exposed 
(Sato, 1992)[14]. The Sr isotopic data obtained by the present study support the conclusion proposed by Blum et al. (1992)[1] that the depositional age of sedimentary target materials is close to $170 \mathrm{Ma}$ (Jurassic). Mixing calculations based on the model proposed by $\mathrm{Ho}$ and Chen (1996)[2] for various amounts and combinations of target rocks indicate that the best fit for tektites from the Dalat area is a mixture of $39 \%$ shale, $29 \%$ sandstone, $32 \%$ greywacke, $1 \%$ quartzite.

\section{References}

[1] J. D. Blum , D. A. Papanastassiou, C. Koeberl, and G. J. Wasserburg, "Nd and $\mathrm{Sr}$ isotopic study of Australasian tektites:New constraints on the provenance and age of target material", Geochim. Cosmochim. Acta, 56, pp. 483-492, 1992.

[2] K. S. Ho, and J. C. Chen, "Geochemistry and origin of tektites from the penglei area, Hainan province, southern China." J. of Southeast Asian Earth Sciences Vol. 13, No. 1, pp. 61-72, 1996.

[3] A. Montanari, and C. Koeberl, "Impact Stratigraphy: The Italian Record." Springer, Heideberg, 2000.

[4] L. Folco, B. P. Glass, M. D’Orazio, P. Rochette, "A common volatilization trend in Transantarctic Mountain and Australasian microtektites: Implications for their formation model and parent crater location." Earth and Planetary Science Letters 293, pp.135-139, 2010.

[5] F. Moynier, P. Beck, F. Jourdan, Q. Z. Yin, U. Reimold, C. Koeberl, "Isotopic fractionation of zinc in tektites." Earth and Planetary Science Letters 277, pp. 482-489, 2009.
[6] B. P. Glass, "Tektites and microtektites: key facts and inferences." Tectonophysics 171, pp. 393-404, 1990.

[7] F. Moynier, C. Koeberl, P. Beck, F. Jourdan, P. Telouk, "Isotopic fractionation of $\mathrm{Cu}$ in tektites." Geochimica et Cosmochimica Acta 74, pp. 799-807, 2010.

[8] Y. T. Lee, J. C. Chen, K. S. Ho and W. S. Juang, "Geochemical studies of tektites from East Asia." Geochem. Jour. 38, pp. 1-17, 2004.

[9] B. P. Glass, H. Huber and C. Koeberl "Geochemistry of Cenozoic microtektites and clinopyroxenebearing sphereules." Geochim. Cosmochim. Acta 68, pp. 3971-4006, 2004.

[10] B. P. Glass and J. E. Pizzuto, "Geographical variation in Australasian microtektite concentrations: Implications concerning the location and size of the source crater." J. Geophys. Res. 99, pp. 19075-19081, 1994.

[11] C. Koeberl, "Geochemistry and origin of Muong Nong-type tektites." Geochim. Cosmochim. Acta 56, pp. 1033-1064, 1992.

[12] C. Koeberl, "Geochemistry and origin of Muong Nong-type tektites." Geochim. Cosmochim. Acta 56, pp. 1033-1064, 1992.

[13] G. Schmidt, L. Zhoi, J. T. Wasson, "Iridium anomaly associated with the Australian tektite-producing impact:Masses of the impactor and of the Australian tektites." Geochim. Cosmochim. Acta 57,pp. 4851-4859, 1993.

[14] T. Sato, "Regional geology and stra tigraphy : Southeast Asia and Japan." In The Jurassic of the CircumPacific(Edited by Westermann G. E. G.), pp. 194-213. Cambridge University Press, 1992. 